\title{
Supplemental Bone Grafting in Giant Cell Tumor of the Extremity Reduces Nononcologic Complications
}

\author{
Joseph Benevenia MD, Steven M. Rivero MD, Jeffrey Moore MD, \\ Joseph A. Ippolito BA, Daniel A. Siegerman MD, Kathleen S. Beebe MD, \\ Francis R. Patterson MD
}

Published online: 1 March 2016

(C) The Association of Bone and Joint Surgeons( 2016

\begin{abstract}
Background Giant cell tumors (GCTs) are treated with resection curettage and adjuvants followed by stabilization. Complications include recurrence, fracture, and joint degeneration. Studies have shown treatment with polymethylmethacrylate (PMMA) may increase the risk of joint degeneration and fracture. Other studies have suggested that subchondral bone grafting may reduce these risks.

Questions/purposes Following standard intralesional resection-curettage and adjuvant treatment, is the use of bone graft, with or without supplemental PMMA, (1) associated with fewer nononcologic complications; (2) associated with differences in tumor recurrence between patients treated with versus those treated without bone grafting for GCT; and (3) associated with differences in Musculoskeletal Tumor Society (MSTS) scores?

Methods Between 1996 and 2014, 49 patients presented with GCT in the epiphysis of a long bone. Six patients were

One or more of the authors (JB) has received funding from the Musculoskeletal Transplant Foundation and has also received fees from Merete Inc (Berlin, Germany) and Implant Cast (Buxtehude, Germany) outside of the submitted work and holds several patents and licensing fees with CreOsso LLC (Montclair, NJ, USA). All ICMJE Conflict of Interest Forms for authors and Clinical Orthopaedics and Related Research ${ }^{\mathbb{B}}$ editors and board members are on file with the publication and can be viewed on request.

Each author certifies that his or her institution approved the human protocol for this investigation, that all investigations were conducted in conformity with ethical principles of research, and that informed consent for participation in the study was obtained.
\end{abstract}

J. Benevenia ( $\square$ ), S. M. Rivero, J. Moore, J. A. Ippolito, D. A. Siegerman, K. S. Beebe, F. R. Patterson

Department of Orthopaedic Surgery, Rutgers New Jersey

Medical School, 140 Bergen Street, ACC Building, Suite

D-1610, Newark, NJ 07103, USA

e-mail: benevejo@njms.rutgers.edu excluded, four who were lost to followup before 12 months and two because they presented with displaced, comminuted, intraarticular pathologic fractures with a nonreconstructable joint surface. The remaining 43 patients were included in our study at a mean followup of 59 months (range, 12-234 months). After resection-curettage, 21 patients were reconstructed using femoral head allograft with or without PMMA (JB) and 22 patients were reconstructed using PMMA alone (FRP, KSB); each surgeon used the same approach (that is, bone graft or no bone graft) throughout the period of study. The primary study comparison was between patients treated with bone graft (with or without PMMA) and those treated without bone graft.

Results Nononcologic complications occurred less frequently in patients treated with bone graft than those treated without (10\% [two of 21] versus 55\% [12 of 22]; odds ratio, 0.088; 95\% confidence interval [CI], 0.02-0.47; $\mathrm{p}=0.002$ ). Patients with bone graft had increased nononcologic complication-free survival (hazard ratio, 4.59; $95 \%$ CI, 1.39-15.12; p = 0.012). With the numbers available, there was no difference in tumor recurrence between patients treated with bone graft versus without (29\% [six of 21 ] versus $32 \%$ [seven of 22]; odds ratio, $0.70 ; 95 \% \mathrm{CI}$, $0.1936-2.531 ; \mathrm{p}=0.586)$ or in recurrence-free survival among patients with bone graft versus without (hazard ratio, $0.94 ; 95 \% \mathrm{CI}, 0.30-2.98 ; \mathrm{p}=0.920)$. With the numbers available, there was no difference in mean MSTS scores between patients treated with bone graft versus without $(92 \% \pm 2 \%$ versus $93 \% \pm 1.4 \%$; mean difference $1.0 \% ; 95 \% \mathrm{CI},-3.9 \%$ to $6.0 \%$; $\mathrm{p}=0.675)$.

Conclusions Compared with PMMA alone, the use of periarticular bone graft constructs reduces postoperative complications apparently without increasing the likelihood of tumor recurrence. 
Level of Evidence Level III, therapeutic study.

\section{Introduction}

Giant cell tumors (GCTs) are most commonly treated with curettage [2]. Curettage alone with an intralesional margin has a recurrence rate of $40 \%$ to $60 \%[2,14,19,29,31]$. Treatment with adjuvants such as high-speed burring, polymethylmethacrylate (PMMA), hydrogen peroxide lavage, phenol cauterization, argon beam, and liquid nitrogen may be used to extend the margin and reduce recurrence rates to as low as $2 \%$ to $18 \%$ [1, 14, 20, 26, 29]. Reconstruction is often performed using PMMA with or without bone grafts and osteosynthesis (Fig. 1). This helps to preserve joint integrity and maximize function without resorting to endoprosthetic replacements. Postoperative fracture and cartilage loss result in degenerative changes and arthritis [2, 7, 17, 23, 27, 29]. The method of skeletal reconstruction may play a role in the future biologic integrity of the joint and result in subsequent fracture and degenerative changes.

Studies have shown that patients benefit from filling the resultant cavity with PMMA, which allows immediate stability and early return to weightbearing postoperatively $[1,3,14]$. Polymerization of the cement is an exothermic reaction, which results in thermal necrosis, extending the mechanical limit of curettage $[2,20]$. When the cement polymerizes directly adjacent to a chondral surface, the exothermal reaction may cause thermal necrosis to the articular chondrocytes and increase the time needed for healing in local tissues $[16,19,21,23,28,30]$. Furthermore, the modulus of PMMA is greater than subchondral bone and cartilage [8, 12, 13, 15, 28]. PMMA directly adjacent to articular cartilage may make the patient more susceptible to postoperative articular fractures and early degenerative osteoarthritis $[2,8,20,24]$. Bone grafting the subchondral plate with or without supplemental PMMA may therefore be more beneficial than PMMA alone.

We asked whether following standard intralesional resection-curettage and adjuvant treatment, the use of bone graft, with or without supplemental PMMA, would (1) reduce the frequency of nononcologic complications associated with the reconstruction; (2) be associated with differences in tumor recurrence between patients treated with versus those treated without bone grafting for GCT; and (3) be associated with differences in Musculoskeletal Tumor Society (MSTS) scores.

\section{Patients and Methods}

This study was approved by the institutional review board at the author's institution and was performed in accordance with the ethical standards of the 1964 Declaration of Helsinki as revised in 2000. Between 1996 and 2014, 49 patients presented with Campanacci Grade 3 [4, 5] GCT in the epiphysis of a long bone. Of these 49 patients, six were excluded as a result of the following: four patients were lost to followup before 12 months and two patients
Fig. 1A-B Reconstructive options include PMMA without graft (A) and PMMA with graft (B).
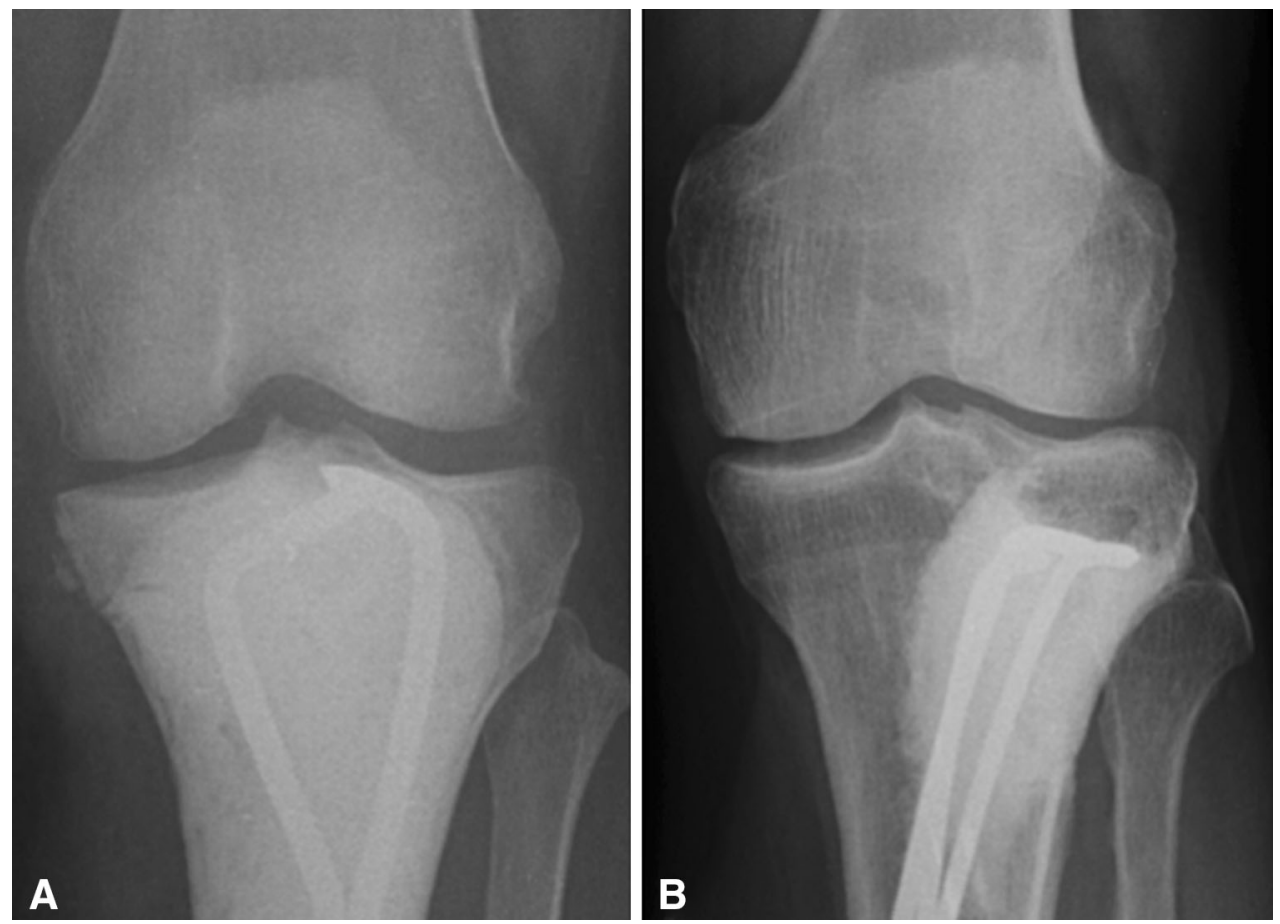
had displaced, comminuted, intraarticular pathologic fractures with a nonreconstructable joint surface. The remaining 43 patients were included in our study at a mean followup of 59 months (range, 12-234 months). After resection-curettage, patients were either reconstructed using supplemental trabecular bone allograft with or without PMMA (JB), or PMMA alone (FRP, KSB). Each surgeon used the same approach (that is, bone graft or no bone graft) throughout the period of study. Nine of the 19 patients who had surgeries performed over 10 years ago were seen within the last 5 years. Of the remaining 10 patients, six were in the PMMA alone group with a mean followup of 27 months (range, 16-39 months) and four were in the bone graft group with a mean followup of 44 months (range, 20-99 months). The primary study comparison was between patients treated with bone graft (with or without PMMA) and those treated without bone graft.

\section{Similarity of Study Groups}

To evaluate the likelihood that factors other than the presence of bone graft might have played a role in reducing nononcologic complications or not, tumor volume, percent articular surface involvement, and method of fixation were analyzed. All patients in both groups had Campanacci Grade 3 tumors. In comparison between patients without bone graft versus patients with bone graft, there were no differences in mean tumor volume $\left(60 \pm 8 \mathrm{~cm}^{3}\right.$ versus $74 \pm 11 \mathrm{~cm}^{3} ; \mathrm{p}=$ 0.266), percent articular surface involvement $(36 \% \pm 4 \%$ versus $43 \% \pm 4 \% ; p=0.203$ ), or method of fixation. In the group without bone graft, method of fixation included threaded Steinmann pins (seven), locking plates (eight), and cortical screws (one). Eight patients had no fixation. In the group with bone graft, method of fixation included threaded Steinmann pins (seven), locking plates (nine), and cortical screws (three). Three patients had no fixation. Comparison of these groups with chi square analysis revealed no difference among the groups $(\mathrm{p}=0.355)$.

\section{Surgical Technique and Aftercare}

After appropriate staging, including radiographs, CT scan, and MRI, biopsy confirmed the lesions. Resection curettage was performed by one of three fellowship-trained orthopaedic oncologists (JB, KSB, FRP) using the same operative techniques. An appropriate-sized cortical window was created to visualize the entire extent of the tumor. The gross tumor was removed by visual inspection and biplanar fluoroscopy. Operative technique was the same among all surgeons. The decision to include bone graft (JB) or not (FRP, KSB) was based on surgeon preference. The cavity was then enlarged with a high-speed burr. Additional adjuvant treatment was administered in the form of argon photocoagulation, hydrogen peroxide solution, and/ or saturated phenol solution based on the standard practice of the operative surgeon. Prophylactic fixation devices were used if deemed necessary by the primary surgeon. Devices used for fixation were similarly distributed between the two groups, which included Steinmann pins, bone plates, and cortical screws. Femoral head allograft was used in all patients in the bone graft group. The defect was measured and allograft was cut 10 to $15 \mathrm{~mm}$ in thickness, sized, and shaped. Next, the allograft was placed under the subchondral plate with provisional Kirschner wire fixation followed by permanent fixation and complete backfilling with PMMA under fluoroscopic guidance. Patients with bone grafting were restricted in weightbearing with toe-touch postoperatively until bony union was noted at a mean of 3 months and then partial weightbearing to full weightbearing as tolerated. Patients with PMMA alone were initially partial weightbearing for 4 to 6 weeks and then weightbearing as tolerated.

\section{PMMA Alone}

Twenty-four reconstructions were performed in 22 patients using PMMA alone. There were eight males and 14 females at a mean of 34 years of age (range, 17-75 years). The mean followup was 56 months (range, 12-135 months). The lesion was located in the distal femur in 11 patients; the proximal tibia in four; the distal tibia in four; and the distal radius, distal humerus, and the acetabulum in one each. All patients received intraoperative adjuvant treatment, which included high-speed burring followed by argon laser with hydrogen peroxide lavage.

\section{Bone Graft With or Without PMMA}

Twenty-one reconstructions were performed in 21 patients using bone graft with or without PMMA as a supplement. There were 11 males and 10 females at a mean of 34 years of age (range, 14-66 years). The mean followup was 63 months (range, 12-234 months). The lesion was located in the distal femur in eight patients, the proximal tibia in 10, and the distal tibia in three. All patients received intraoperative adjuvant treatment with high-speed burring followed by argon laser with hydrogen peroxide lavage in 20 and by phenol in one patient. 
Study Outcomes

All endpoints were assessed by chart review performed by the operating surgeons (JB, FRP, KSB), including evidence of postoperative healing, infection, reoperation, fracture, osteoarthritis, and tumor recurrence (Fig. 2). Functional evaluation was performed using the MSTS scoring system when rehabilitation was complete [9].

Articular fractures and osteoarthritis, considered to be nononcologic complications, were clinically symptomatic and confirmed radiographically. Although plain radiographs were the primary method of identification, CT scans and MRIs were used as confirmatory studies in patients when subchondral fracture or recurrence was suspected. Tumor recurrences, when suspected, were biopsied and subsequently treated with repeat resection-curettage and adjuvants when possible.

\section{Statistical Analysis}

Postoperative complications from each group were compared using a chi square test. Functional evaluations (MSTS scores) were compared between the two groups using a Welch's t-test. Nononcologic complication-free and recurrence-free survival was calculated by the KaplanMeier method and evaluated by the log-rank test and are reported as a hazard ratio and $95 \%$ confidence interval. A p value of $\leq 0.05$ was deemed statistically significant for all statistical analyses. Statistical analyses were conducted using GraphPad Prism Version 6.0 for Mac (GraphPad Software, La Jolla, CA, USA).

\section{Results}

Nononcologic complications occurred less frequently in patients treated with bone graft than those treated without ( $10 \%$ [two of 21 ] versus $55 \%$ [12 of 22]; odds ratio [OR], $0.088 ; 95 \%$ confidence interval [CI], 0.02-0.47; $\mathrm{p}=0.002$ ). Kaplan-Meier survival analysis revealed increased nononcologic complication-free survival (hazard ratio [HR], 4.59; 95\% CI, 1.39-15.12; $\mathrm{p}=0.012$ ) (Fig. 3). Of two nononcologic complications in the bone graft group, one was a periarticular fracture and one was a progression to osteoarthritis (Table 1). Of 12 nononcologic complications in the group without bone graft, five were periarticular fractures and seven were progressions to osteoarthritis (Table 2). With

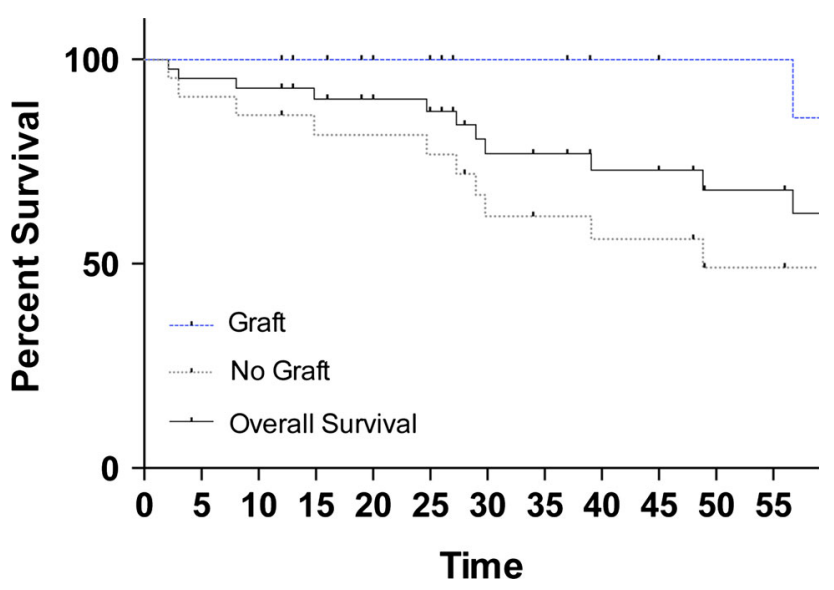

Fig. 3 Kaplan-Meier survival curve showing increased nononcologic complication-free survival in patients with bone graft (HR, 4.59; $95 \%$ CI, 1.39-15.12; $\mathrm{p}=0.012$ ).
Fig. 2A-B Postoperative nononcologic complications include fracture $(\mathbf{A})$ and osteoarthritis (B).
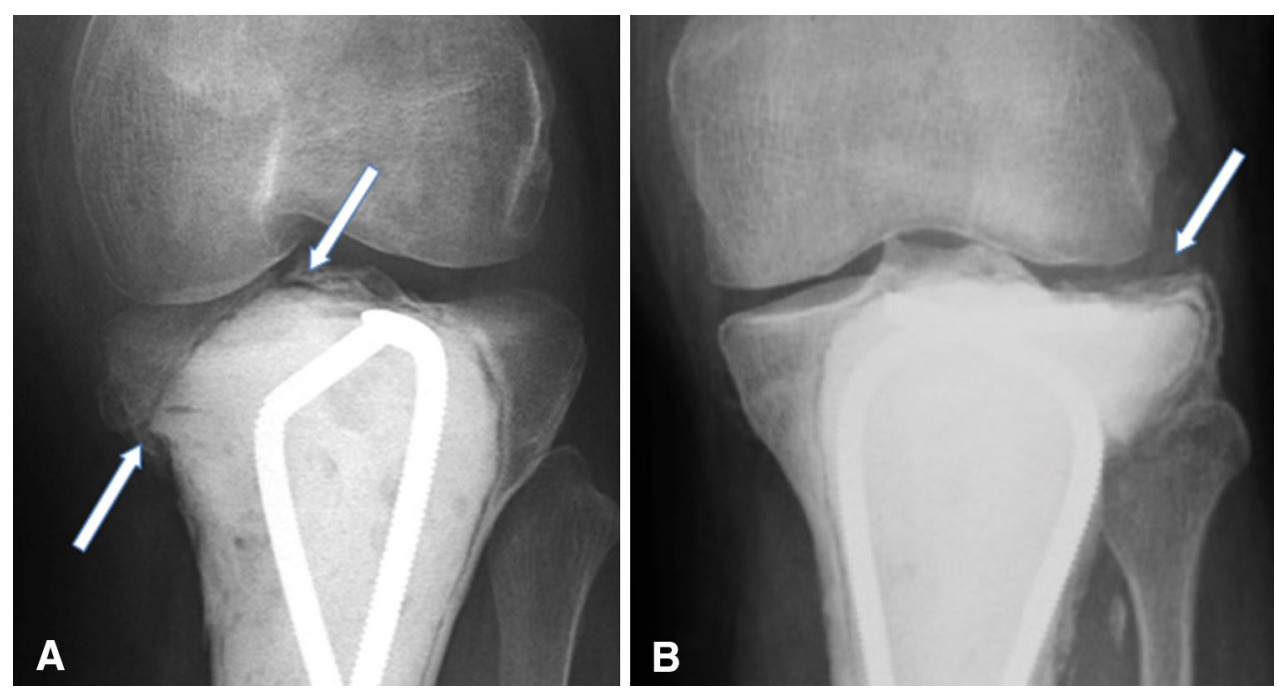


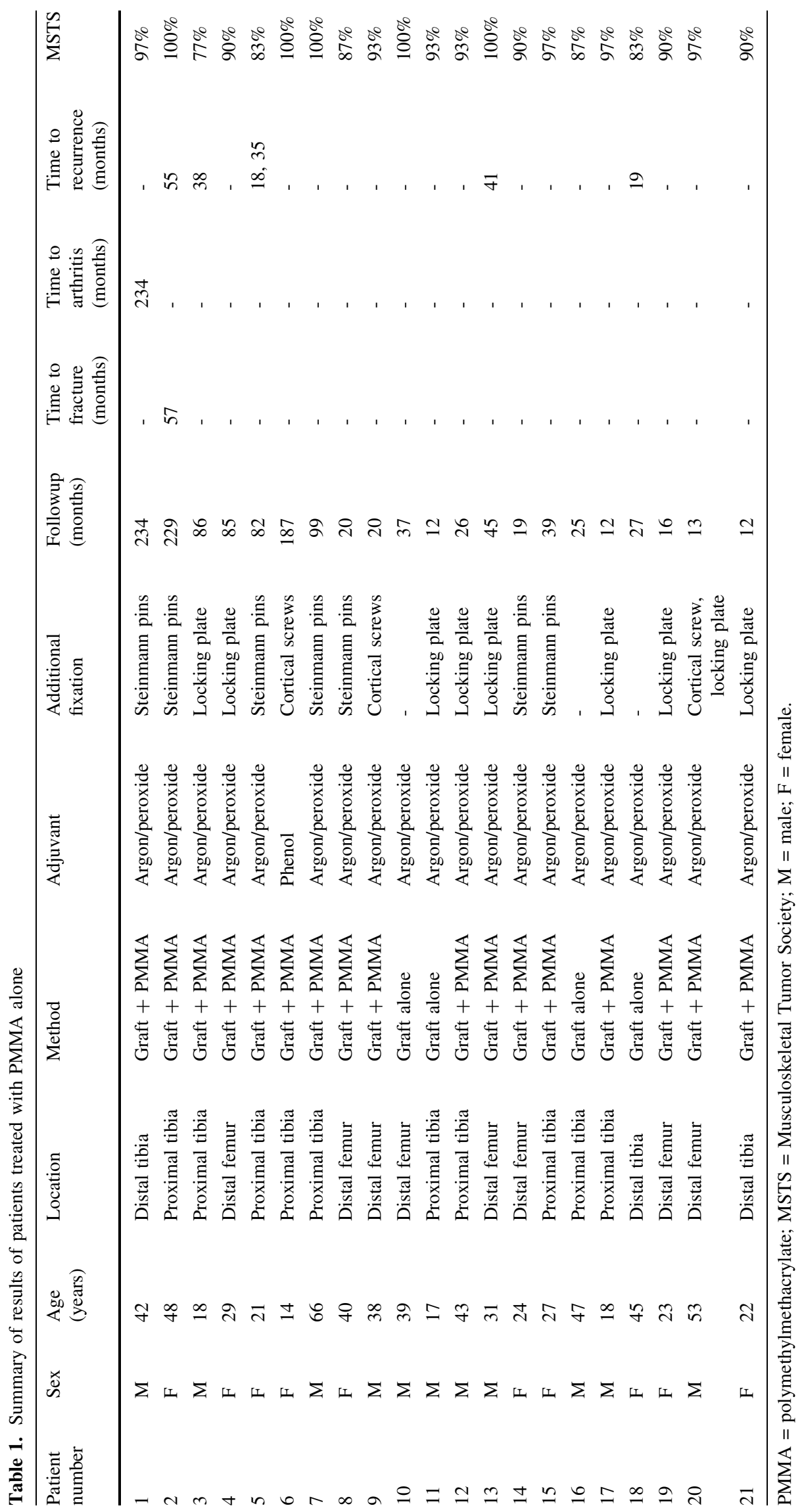


Table 2. Summary of results of patients treated with bone graft with or without PMMA

\begin{tabular}{|c|c|c|c|c|c|c|c|c|c|c|c|}
\hline $\begin{array}{l}\text { Patient } \\
\text { number }\end{array}$ & Sex & $\begin{array}{l}\text { Age } \\
\text { (years) }\end{array}$ & Location & Method & Adjuvant & $\begin{array}{l}\text { Additional } \\
\text { fixation }\end{array}$ & $\begin{array}{l}\text { Followup } \\
\text { (months) }\end{array}$ & $\begin{array}{l}\text { Time to } \\
\text { fracture } \\
\text { (months) }\end{array}$ & $\begin{array}{l}\text { Time to } \\
\text { arthritis } \\
\text { (months) }\end{array}$ & $\begin{array}{l}\text { Time to } \\
\text { recurrence } \\
\text { (months) }\end{array}$ & MSTS \\
\hline $1^{*}$ & $\mathrm{~F}$ & 28 & Distal femur & PMMA alone & Argon/peroxide & - & 39 & 27 & - & 27 & $100 \%$ \\
\hline 2 & $\mathrm{~F}$ & 36 & Proximal tibia & PMMA alone & Argon/peroxide & Steinmann pins & 97 & 3 & - & - & $83 \%$ \\
\hline 3 & M & 25 & Distal femur & PMMA alone & Argon/peroxide & Locking plate & 84 & 8 & - & 8 & $87 \%$ \\
\hline 4 & M & 41 & Distal tibia & PMMA alone & Argon/peroxide & Steinmann pins & 16 & 2 & 4 & - & $93 \%$ \\
\hline 5 & M & 31 & Proximal tibia & PMMA alone & Argon/peroxide & Steinmann pins & 100 & - & 30 & 30 & $90 \%$ \\
\hline $6^{*}$ & M & 18 & Distal tibia & PMMA alone & Argon/peroxide & Steinmann pins & 84 & - & - & 19,23 & $90 \%$ \\
\hline 7 & M & 31 & Distal femur & PMMA alone & Argon/peroxide & Locking plate & 34 & - & - & - & $97 \%$ \\
\hline 8 & $\mathrm{~F}$ & 28 & Distal femur & PMMA alone & Argon/peroxide & - & 56 & - & - & - & $97 \%$ \\
\hline 9 & $\mathrm{~F}$ & 53 & Distal tibia & PMMA alone & Argon/peroxide & Cortical screws & 18 & - & - & - & $80 \%$ \\
\hline 10 & $\mathrm{~F}$ & 27 & Distal femur & PMMA alone & Argon/peroxide & - & 36 & - & - & - & $97 \%$ \\
\hline 11 & $\mathrm{~F}$ & 52 & Distal femur & PMMA alone & Argon/peroxide & Steinmann pins & 24 & - & - & - & $100 \%$ \\
\hline 12 & $\mathrm{~F}$ & 41 & Proximal tibia & PMMA alone & Argon/peroxide & - & 135 & - & - & - & $100 \%$ \\
\hline 13 & M & 29 & Proximal tibia & PMMA alone & Argon/peroxide & Steinmann pins & 33 & - & - & - & $100 \%$ \\
\hline 14 & $\mathrm{~F}$ & 75 & Distal radius & PMMA alone & Argon/peroxide & - & 49 & 30 & - & - & $100 \%$ \\
\hline 15 & $\mathrm{~F}$ & 22 & Distal femur & PMMA alone & Argon/peroxide & - & 28 & - & - & - & $77 \%$ \\
\hline 16 & $\mathrm{~F}$ & 62 & Distal femur & PMMA alone & Argon/peroxide & Locking plate & 48 & - & 15 & - & $90 \%$ \\
\hline 17 & M & 34 & Distal femur & PMMA alone & Argon/peroxide & Locking plate & 48 & - & - & - & $90 \%$ \\
\hline 18 & $\mathrm{~F}$ & 17 & Distal femur & PMMA alone & Argon/peroxide & Locking plate & 49 & - & - & 5 & $93 \%$ \\
\hline 19 & M & 24 & Distal tibia & PMMA alone & Argon/peroxide & Locking plate & 55 & - & 49 & - & $97 \%$ \\
\hline 20 & $\mathrm{~F}$ & 22 & Distal femur & PMMA alone & Argon/peroxide & - & 48 & - & - & - & $97 \%$ \\
\hline 21 & $\mathrm{~F}$ & 21 & Distal femur & PMMA alone & Argon/peroxide & - & 12 & - & - & - & $93 \%$ \\
\hline 22 & $\mathrm{~F}$ & 28 & Distal humerus & PMMA alone & Argon/peroxide & Locking plate & 132 & - & 39 & 45 & $63 \%$ \\
\hline
\end{tabular}

* Patients had a second reconstruction; PMMA = polymethylmethacrylate; MSTS = Musculoskeletal Tumor Society; F = female; M = male.

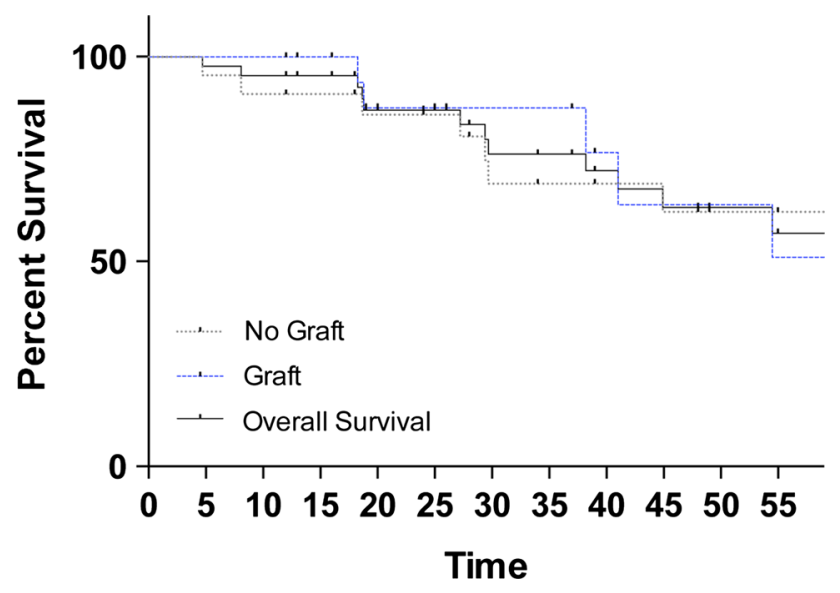

Fig. 4 Kaplan-Meier survival curve showing no difference in recurrence-free survival among patients with bone graft versus without (HR, 0.94; 95\% CI, 0.30-2.98; $\mathrm{p}=0.920$ ).

the numbers available, there was no difference in mean tumor volume between patients with nononcologic complications versus without $\left(61 \pm 10 \mathrm{~cm}^{3}\right.$ versus $\left.74 \pm 9 \mathrm{~cm}^{3} ; \mathrm{p}=0.402\right)$ or in mean percent articular surface involvement $(45 \% \pm 7 \%$ versus $39 \% \pm 3 \% ; \mathrm{p}=0.376$ ),
With the numbers available, there was no difference in tumor recurrence between the group treated with bone graft and the group treated without it (29\% [six of 21] versus 32\% [seven of 22]; OR, 0.70; 95\% CI, 0.1936-2.531; $\mathrm{p}=0.586$ ). Kaplan-Meier survival analysis revealed no difference in recurrence-free survival (HR, 0.94; 95\% CI, 0.30-2.98; $\mathrm{p}=$ 0.920) (Fig. 4). In both groups, one patient had a second recurrence. In patients with tumor recurrence compared with those without, with the numbers available, there was no difference in mean tumor volume $\left(67 \pm 11 \mathrm{~cm}^{3}\right.$ versus $70 \pm 9$ $\left.\mathrm{cm}^{3} ; \mathrm{p}=0.816\right)$ or percent articular surface involvement $(46 \% \pm 5 \%$ versus $40 \% \pm 3 \% ; p=0.388)$.

With the numbers available, there was no difference in mean MSTS scores between the group treated with bone graft and the group treated without it $(92 \% \pm 2 \%$ versus $93 \% \pm$ $1 \%$; mean difference $1.0 \%$; $95 \% \mathrm{CI},-4 \%$ to $6 \% ; \mathrm{p}=0.675$ ).

\section{Discussion}

After curettage, treatment with adjuvants including highspeed burring, PMMA, hydrogen peroxide lavage, phenol cauterization, argon beam, and liquid nitrogen reduces 
recurrence rates to as low as $2 \%$ to $18 \%[1,14,20,26,29]$. PMMA directly adjacent to articular cartilage may contribute to an increased risk of postoperative articular fractures and early degenerative osteoarthritis $[2,8,20$, 24]. This study directly compares reconstruction using bone graft with or without PMMA versus PMMA alone at the same institution. Our results demonstrate that subchondral bone grafting decreases nononcologic complications in patients treated for GCT.

This study should be interpreted in light of its limitations. Like in many orthopaedic oncology studies, the number of patients is limited, the study was retrospective, and patients were not randomized to the treatment groups. Although patients were not randomized, no differences were found between the groups among mean tumor volume, mean percent articular surface involvement, or method of fixation. Surgeon preference dictated use of bone graft (JB) or not (FRP, KSB); however, each of those three surgeons treated all patients in the same way (that is JB used bone graft in all patients and FRP and KSB did not use bone graft) throughout this study period, and in other respects, the surgical technique was similar among three fellowship-trained orthopaedic oncologists. Additionally, 10 patients who had their procedures performed greater than 10 years ago have not been seen within the last 5 years. Of these patients, six were in the group without graft (27\%, the number of patients not seen of all patients in their respective group [PMMA alone or graft]) with a mean followup of 27 months (range, 16-39 months) and four $(19 \%)$ were in the bone graft group with a mean followup of 44 months (range, 20-99 months).

We found fewer nononcologic complications, including fractures and arthritis, in the group treated with bone graft. It has been suggested that thermal damage from PMMA can contribute to postoperative degenerative changes [8, $16,22,23,25,30]$. When used in conjunction with PMMA, bone graft increases the distance between the exothermic reaction of PMMA and the articular cartilage, which may protect against thermal injury [3, 13, 21, 23]. Wilkins et al. suggested irrigation of the periarticular area with chilled saline as the cement cures as a method of prevention from heat necrosis [33]. The mechanical properties of PMMA, compared with bone graft, may also influence the rates of articular fracture and osteoarthritis. PMMA has a modulus that is between cortical bone and cancellous bone and well above articular cartilage. PMMA acts as a rigid surface, concentrating pressure on the already thin cartilage and subchondral plate tissue [13, 15, 24]. This may result in cartilage damage, fracture, and arthrosis $[13,15,28]$. Bone graft has the ability to incorporate into host bone and more adequately restore the subchondral and cancellous positions of the joint surface $[7,8,32]$.
Although PMMA thermal necrosis has been shown to reduce local recurrence, other adjuvants have also been successful $[14,18,24]$. In the current study we found no difference in the proportion of patients experiencing recurrence between the two study groups. This may be attributed to adjuvant therapies performed along with curettage in both groups, including high-speed burring, argon photocoagulation, phenol, and peroxide lavage.

With the numbers available, we found no differences between patients treated with and those treated without bone graft in terms of a validated outcomes score (the MSTS score). Others have found similar results. Szalay et al. [25] compared results of patients treated with bone graft versus cement and found comparable mean MSTS scores of $91 \%$ and $90 \%$, respectively. In patients treated with PMMA with or without bone graft, van der Heijden et al. [28] found mean MSTS scores of $70 \%$ and $80 \%$ in patients with or without postoperative arthritis, respectively. Fraquet et al. [11] found mean MSTS scores of 93\% in patients treated with curettage and cementation. Errani et al. [10] found mean MSTS scores of $92 \%$ and $94 \%$ for patients treated with two adjuvants versus three adjuvants, respectively. Chen et al. [6] found mean MSTS scores of $88 \%$ in patients who underwent intralesional curettage.

The results of this study indicate that the use of bone graft, with or without PMMA, shows promise in limiting early postoperative complications. With the numbers available, we found no difference between patients treated with and those treated without bone graft with respect to local recurrence or MSTS scores. In this small series, we found no additional harm to the patients treated with grafting, and we saw some evidence that this approach may help prevent early postoperative complications. In light of these results, we recommend the use of bone graft, with or without PMMA, over the use of PMMA alone for repair of subchondral bone defects after tumor resection. Future studies might include a multiinstitutional, prospective, randomized study to further investigate the role of bone graft in reducing nononcologic complications in patients with GCT, the role of denosumab in downstaging tumor volume, and the use of ceramic biomaterials with similarities in modulus to subchondral bone.

\section{References}

1. Alkalay D, Kollender Y, Mozes M, Meller I. Giant cell tumors with intraarticular fracture. Two-stage local excision, cryosurgery and cementation in 5 patients with distal femoral tumor followed for 2-4 years. Acta Orthop Scand. 1996;67:291-294.

2. Bini SA, Gill K, Johnston JO. Giant-cell tumor of bone-curettage and cement reconstruction. Clin Orthop Relat Res. 1995;321:245-250.

3. Blackley HR, Wunder JS, Davis AM, White LM, Kandel R, Bell RS. Treatment of giant-cell tumors of long bones with curettage and bone-grafting. J Bone Joint Surg Am. 1999;81:811-820. 
4. Campanacci M. Giant-cell tumor and chondrosarcomas: grading, treatment and results (studies of 209 and 131 cases). Recent Results Cancer Res. 1976:257-261.

5. Campanacci M, Baldini N, Boriani S, Sudanese A. Giant-cell tumor of bone. J Bone Joint Surg Am. 1987;69:106-114.

6. Chen TH, Su YP, Chen WM. Giant cell tumors of the knee: subchondral bone integrity affects the outcome. Int Orthop. 2005;29:30-34.

7. Chu KT, Oshida Y, Hancock EB, Kowolik MJ, Barco T, Zunt SL. Hydroxyapatite/PMMA composites as bone cements. Biomed Mater Eng. 2004;14:87-105.

8. Crawford K, Berrey BH, Pierce WA, Welch RD. In vitro strength comparison of hydroxyapatite cement and polymethylmethacrylate in subchondral defects in caprine femora. J Orthop Res. 1998;16:715-719.

9. Enneking WF, Dunham W, Gebhardt MC, Malawar M, Pritchard DJ. A system for the functional evaluation of reconstructive procedures after surgical treatment of tumors of the musculoskeletal system. Clin Orthop Relat Res. 1993;286:241246.

10. Errani C, Ruggieri P, Asenzio MA, Toscano A, Colangeli S, Rimondi E, Rossi G, Longhi A, Mercuri M. Giant cell tumor of the extremity: a review of 349 cases from a single institution. Cancer Treat Rev. 2010;36:1-7.

11. Fraquet N, Faizon G, Rosset P, Phillipeau J, Waast D, Gouin F. Long bones giant cells tumors: treatment by curretage and cavity filling cementation. Orthop Traumatol Surg Res. 2009;95:402406.

12. Hill C, Wingerter S, Parsell D, McGuire R. Vertebral compression model and comparison of augmentation agents. Evid Based Spine Care J. 2011;2:23-27.

13. Hisatome T, Yasunaga Y, Ikuta Y, Fujimoto Y. Effects on articular cartilage of subchondral replacement with polymethylmethacrylate and calcium phosphate cement. J Biomed Mater Res. 2002;59:490-498.

14. Jamshidi K, Sami S, Modares-Nejad HR, Johansoz A. Local recurrence in giant cell tumor of bone: Comparitive study of two methods of surgical approach. J Res Med Sci. 2008;13: 223-229.

15. Manley PA, McKeown DB, Schatzker J, Palmer NC, Carman S. Replacement of epiphyseal bone with methylmethacrylate: its effect on articular cartilage. Arch Orthop Trauma Surg. 1982;100:3-10.

16. Mjöberg B, Pettersson $\mathrm{H}$, Rosenqvist $\mathrm{R}$, Rydholm A. Bone cement, thermal injury and the radiolucent zone. Acta Orthop Scand. 1984;55:597-600.

17. Mousa WF, Kobayashi M, Shinzato S, Kamimura M, Neo M, Yoshihara S, Nakamura T. Biological and mechanical properties of PMMA-based bioactive bone cements. Biomaterials. 2000;21:2137-2146.

18. O'Donnell RJ, Springfield DS, Motwani HK, Ready JE, Gebhardt MC, Mankin HJ. Recurrence of giant-cell tumors of the long bones after curettage and packing with cement. J Bone Joint Surg Am. 1994;76:1827-1833.
19. Persson BM, Ekelund L, Lövdahl R, Gunterberg B. Favourable results of acrylic cementation for giant cell tumors. Acta Orthop Scand. 1984;55:209-214.

20. Pritsch T, Bickels J, Wu CC, Squires HM, Malawer MM. The risk for fractures after curettage and cryosurgery around the knee. Clin Orthop Relat Res. 2007;458:159-167.

21. Radev BR, Kase JA, Askew MJ, Weiner SD. Potential for thermal damage to articular cartilage by PMMA reconstruction of a bone cavity following tumor excision: s finite element study. J Biomech. 2009;42:1120-1126.

22. Radin EL, Martin RB, Burr DB, Caterson B, Boyd RD, Goodwin C. Effects of mechanical loading on the tissues of the rabbit knee. J Orthop Res. 1984;2:221-234.

23. Schatzker J, Horne JG, Sumner-Smith G, Sanderson R, Murnaghan JP. Methymethacrylate cement: its curing temperature and effect on articular cartilage. Can J Surg. 1975;18:172-175, 178.

24. Suzuki Y, Nishida Y, Yamada Y, Tsukushi S, Sugiura H, Nakashima H, Ishiguro N. Re-operation results in osteoarthritic change of knee joints in patients with giant cell tumor of bone. Knee. 2007;14:369-374.

25. Szalay K, Antal I, Kiss J, Szendroi M. Comparison of the degenerative changes in weight-bearing joints following cementing or grafting techniques in giant cell tumour patients: medium-term results. Int Orthop. 2006;30:505-509.

26. Thomas DM, Skubitz KM. Giant cell tumour of bone. Curr Opin Oncol. 2009;21:338-344.

27. Toy PC, France J, Randall RL, Neel MD, Shorr RI, Heck RK. Reconstruction of noncontained distal femoral defects with polymethylmethacrylate and crossed-screw augmentation: a biomechanical study. J Bone Joint Surg Am. 2006;88:171-178.

28. van der Heijden L, van de Sande MAJ, Heineken AC, Fiocco M, Nelissen RGHH, Dijkstra PDS. Mid-term outcome after curettage with polymethylmethacrylate for giant cell tumor around the knee: higher risk of radiographic osteoarthritis? J Bone Joint Surg Am. 2013;95:e1591.

29. Vidyadhara S, Rao SK. Techniques in the management of juxtaarticular aggressive and recurrent giant cell tumors around the knee. Eur J Surg Oncol. 2007;33:243-251.

30. Wada T, Kaya M, Nagoya S, Kawaguchi S, Isu K, Yamashita T, Yamawaki S, Ishii S. Complications associated with bone cementing for the treatment of giant cell tumors of bone. J Orthop Sci. 2002;7:194-198.

31. Ward WG Sr, Li G 3rd. Customized treatment algorithm for giant cell tumor of bone: report of a series. Clin Orthop Relat Res. 2002;397:259-270.

32. Welch RD, Berry BH, Crawford K, Zhang H, Zobitz M, Bronson D, Krishnan S. Subchondral defects in caprine femora augmented with in situ setting hydroxyapatite cement, polymethylmethacrylate, or autogenous bone graft: biomechanical and histomorphological analysis after two-years. J Orthop Res. 2002;20:464-472.

33. Wilkins RM, Okada Y, Sim FH. Methyl Methacrylate Replacement of Subchondral Bone: a Biomechanical, Biochemical, and Morphologic Analysis. New York, NY, USA: Churchill Livingstone; 1987. 